\title{
CORRIGENDUM
}

\section{Effect of varying protein and energy intakes on nitrogen balance} in Indian preschool children

\author{
By A. K. IYENGAR, B.S. NARASINGA RAO \\ AND VINODINI REDDY \\ Vol. 42 (1979), no. 3
}

Page 422, line 15

For a diet providing $70 \mathrm{~g}$ protein-energy $/ \mathrm{kg}$.

Read a diet in which $7 \%$ of the total energy was derived from protein.

Page 423, line 7

For diets which contain $70 \mathrm{~g}$ protein energy $/ \mathrm{kg}$.

Read diets which contain $7 \%$ of total energy in the form of protein.

Page 423, lines 8-9

For the diet would have to provide $90-100 \mathrm{~g}$ of protein-energy $/ \mathrm{kg}$.

Read the diet would have to provide $9-10 \%$ of the total energy in the form of protein energy.

Page 423, lines 10-11

For in India provide approximately $110-120 \mathrm{~g}$ protein-energy $/ \mathrm{kg}$.

Read in India provide approximately $11-12 \%$ of total energy in the form of protein energy. 